\title{
ASSESSMENT OF SERVICE QUALITY AND CONSUMER SATISFACTION IN A HUNGARIAN SPA
}

\author{
Zsuzsanna LŐKE ${ }^{\mathrm{a}}$, Ernő KOVÁCS ${ }^{\mathrm{a}}$, Zsuzsanna BACSI $^{\mathrm{a}}$ \\ ${ }^{a}$ University of Pannonia Georgikon Faculty, Gazdasági, Társadalomtudományi és Vidékfejlesztési \\ Tanszék, Keszthely, Deák Ferenc str. 16. 8360-Hungary email: loke@georgikon.hu, kovacs- \\ e@georgikon.hu, h5519bac@ella.hu
}

Cite this article: Löke, Z., Kovács, E., Bacsi, Z. (2018). Assessment Of Service Quality And Consumer Satisfaction In A Hungarian Spa. Deturope, 10(2), 124-146.

\begin{abstract}
The present analysis was carried out at one of the most important medical tourism service providers, the Hévíz Spa and St. Andrew Hospital for Rheumatic Diseases. The institution provides spa services in two locations: in the medicinal lake of Hévíz and in the 7 pools of the pool spa. The present research carried out a single cross-sectional survey of the service quality and consumer satisfaction both in the lake and in the pool bath. Altogether 300 consumers were surveyed between 27 February and 31 March 2017. The questionnaire included the double list of questions of the SERVQUAL method, about performance and importance of various factors.

The customers of the two service locations significantly differ: while the customers of the medicinal lake are mainly guests paying for themselves, $70 \%$ of the customers in the pool bath are patients supported by the National Health Insurance Fund.

The results of the survey (with 4.64 as the average grade of quality on a 5 - point scale) reflects the high service quality of the spa. Although the difference between the guests and the patients in the evaluation of the importance of various quality factors was not proven, there is a tendency of different ranking of the importance factors and the service quality factors (i.e. reliability, assurance, empathy, responsiveness, tangibles). The graphical representation of the values and importance made it possible to identify the quality factors that require urgent improvement, in order to provide better service quality for both the patients and the guests.

Analysis of variance proved that the patients supported by the National Health Insurance Fund were more satisfied at both locations than guests paying for themselves. The high level of patient satisfaction is a very useful fact for the Hévíz Spa, because the level of satisfaction positively affects recommendations. This positive word of mouth promotion is highly valuable considering the fact, that the legislation in Hungary does not allow the promotion of health services.
\end{abstract}

Keywords: spa, service quality, SERVQUAL, customer satisfaction, Hévíz

\section{INTRODUCTION}

\section{The world of intangible problem solving from a marketing viewpoint}

Services are defined by Kotler (1992) as all activities or performances that one party can offer to another, that are not materialised, and do not result in an ownership right over anything. The provision of services may or may not be linked to a physical product. In other words, the service is a non-physical solution to a problem (Veres 2009). In contrast to a physical product, services are not only intangible, but are also characterised by the fact, that consumers 
cannot own them after the purchase. They are usually performances or processes, which cannot be possessed (Kenesei \& Kolos, 2007).

The problematic features of services are usually referred to as the HIPI principle: Heterogeneity, Intangibility, Perishability, Inseparability. The primary source of the problem is the intangibility of the offer of the service provider. In contrast to the material product services cannot be discovered by seeing, touching, tasting, smelling, or hearing (Kotler \& Keller, 2012), therefore their quality is difficult to estimate. Services, therefore, will have to be purchased at least once, without any preliminary comparison (a "product sample"), in order to experience their quality. This fact explains the importance of word-of-mouth promotion for services (Veres, 2009). The variability of services is the result of the human factor. The higher importance of the human factor in a service increases the risk of variability (Karakasné Morvay, 2014). Perishability is a seemingly advantageous feature of services, as there is no cost of inventory, storage, transportation, but in real life this fact is a considerable disadvantage. In the case of material products the possibility of storing, as a puffer, can overcome the sudden changes of demand. As this is not possible for services, there will be peaks of demand, when some of the demand cannot be satisfied (i.e. customers will be lost), and at times of very low demand the capacities will remain unused (Veres, 2009). Inseparability means, that for most of the services the creation and the consumption happens simultaneously. The customer is also involved in the production process, and the person of the customer (as the input of the service, that cannot be standardised) influences the final quality of the service.

In the colourful world of services the range of health tourism services mean services that are provided with the involvement of both the person providing the service and the customer purchasing the service, and besides intangibility they include another considerable risk component. The frontline staff becomes a key component, functioning as the face of the service provider. Therefore, to achieve customer satisfaction, and the necessary high quality service provision, the selection, sustained motivation, and satisfaction of the service staff are also crucial (Kenesei \& Kolos, 2007). The customer is also involved, thus becoming an influencing factor in performance. The stable quality of service provision does not only depend on staff performance. The "non-standardised input", incorporated into the service creates considerable risk. It is particularly true for health services, that failed fulfilment of the service can lead to damage that is several grades higher than the value of the service transaction (Veres, 2009). In addition, for the confidential services of health tourism, marketing has to be used for informing the customer about the benefits of the service. 
The service staff must precisely and professionally know the services provided. Useful marketing tools are the information boards placed at the entrance or in the lobby of the spa about the contents of the medicinal water or the diseases for which the water is beneficial, indications and counter-indications, or, as in the Hévíz Spa, the exhibition describing the history of the spa. The mouth-of-word promotion of the intangible services helps the opinion seekers, who do not have any information about the services, and to minimise risks and making the best decisions, will have to rely on others for recommendations (Murray, 1991). Therefore the very satisfied customers will not only become returning customers, but will provide positive word-of-mouth promotion improving the image of the service provider.

\section{Value, quality, satisfaction}

Utility, or value are called by Kotler and Keller (2012) the "triad of consumer value" determined by quality, service durability, and price, including a mix of tangible and intangible factors. Better quality and improved service provision increases value, while rising prices will decrease consumer utility. The perceived consumer utility is the difference of total consumer utility and total consumer cost, where total consumer utility is the economic, functional and psychological value of the product, service provision, staff and image, while total consumer cost is the money and non-money expenditures that the consumer spent on accessing the product (the sum of the time, the effort and energy, the psychological and financial costs spent on accessing and using the product (Kotler \& Keller, 2012; Rekettye, 2008, 2004). For this Rekettye (1997) uses the formula:

\section{Perceived value $=$ perceived utility of the product / perceived consumer costs}

A high quality service means competitive advantage for a company, if, as a result, it can attract and retain customers. Quality, however, has to be seen from the customer's viewpoint (Doležalová et al., 2017). Service quality is defined by Kenesei \& Kolos (2007) as "the difference between the customer's expectations and experiences; the more the experiences overcome the expectations, the higher is the quality perceived". Service quality can be understood as the utility reflected by the consumer value judgement, ".... suitability for use" (Tomcsányi, 1994). In his book entitled the basic book of service quality Veres (2009) underlines, that the concept of quality can be generalised only with limitations, as it is influenced by subjective factors, and not all of its parameters are measurable, some of these are only measurable by estimations, and the general judgement about the quality of a service may differ from evaluation of the quality of a particular occasion. Besides the technical 
quality of a service, at least as important - or even more important, unique - feature is the functional quality, i.e., the way of providing the service, e.g. the kindness and friendliness shown by staff, the speed and ease of the service provision process (Kenesei \& Kolos, 2007).

The customers' preliminary expectations have a high weight in assessing the quality of the service provided. Expectations (expected quality, expected service) are formed by the customers' earlier experiences, the recommendations and suggestions by friends, word-ofmouth promotion, but informal sources and the promises by competitors and the marketing communication by the service provider are also important (Webster, 1991; Kotler \& Keller, 2012). An example for the disadvantageous impact of the latter may be a commercial that promises unrealistic benefits, exaggerating the favourable features of the service, thus creating unreasonably high consumer expectations, that the service provider is unable to satisfy even if the service is of good quality. A contrary process is a situation when the consumer shows tolerance towards a vis maior situation that the service provider cannot avoid, and expanding the tolerance zone accepts a less than perfect service as satisfactory - e.g. as in the case of a natural catastrophe (Kenesei \& Kolos, 2007).

Satisfaction reflects the comparative judgements of the person about the perceived performance of the product based on the person's own experiences (Kotler \& Keller, 2012). In other words, it is the extent to which the product matches the consumer expectations. When the performance matches expectations, the consumer is satisfied. When expectations are not met, the consumer is disappointed. When, however, the performance is above the expectations, the consumer becomes overly satisfied, or in other words, happy. Satisfaction, in general, is, therefore, the happiness or disappointment generated by the difference between the expected and the experienced service. Kenesei and Kolos (2007) state that in order to retain comparative advantage, it is not enough to achieve customer satisfaction, the customer should experience bliss: It is not enough to provide services perfectly, but by providing service performance highly above customer expectations the emotional level of bliss should be achieved.

\section{Methods for measuring quality and satisfaction for services}

As high quality and the satisfied customer are crucial factors in retaining the competitive advantage of a company, customer satisfaction has to be systematically measured (Ko \& Pastore, 2005). Satisfaction is a reflection of the customer orientation of the company, and helps to reveal the strengths and weaknesses of the service, to improve quality. The more 
competitive is a sector, the more important is quality and satisfaction research in marketing (Zeithaml \& Bitner, 1996). This is true even if the way of satisfaction evaluation is less exact in the service sector, than in material production.

Information can be collected by objective and subjective methods. Objective methods include measurable parameters, e. Sales revenue, market share, migration, consumer retain rate, returning customer rate. Subjective explicit methods require the questioning of the customer, implicit methods require the questioning of staff, and mystery shopping (Filiatrault, Harvey, \& Chebat, 1996).

Another method, the Critical Incident Technique (CIT) is an interactive method in relation to a specific event, which, although rather unreliable, can be very helpful in identifying mistakes and deficiencies (Friman 2004). Larger service providers also use the technique of mystery shopping (mystery guest). In this technique a well-trained observer, disguised as a customer, tests the service process, focusing on the expectations of normal customers. Another quality assessment method, suitable for discovering service deficiencies, is the Fishbone diagram and Blueprinting (Brown, Gummesson, Edvardsson, \& Gustavsson, 1991). The Fishbone diagram is a graphical presentation tool for the possible causes of quality deficiencies. Nowadays companies become increasingly to complaint - friendly, who offer easy ways for customers to make complaints, because they have understood that fast and efficient handling of customer complaints is an excellent tool for repairing deficiencies and stopping negative word-of-mouth statements, which would undermine the effects of promotion.

The systematic discovery of complaint situations lead to eliminating the occurrence of complaints, which is particularly important for health services in health tourism, because health-related services are confidential, and the risk associated with deficient, or poorly performed services is unacceptably high in certain service sectors, including health services (Veres, 2009). Finally, image profiles can also be used for assessing customer satisfaction, visually presenting the positive and less-than-perfect features of the service.

The most widely used service quality research has been published by Parasuraman, Zeithaml, and Berry (1985a). In this research they identified the following factors that influence the judgement of quality: 1. reliability, 2. responsiveness, 3. competence, 4. access, 5. courtesy, 6. communication, 7. credibility, 8. security, 9. empathy 10. tangible components. To measure the expected and experienced service quality they listed 97 pairs of statements about these factors, and then, filtering out the related factors identified 5 core factors, thus 
creating the SERVQUAL (SERVice QUALity) method (Brown et al., 1991). The following 5 factors were eventually identified: 1. reliability, 2. assurance, 3. tangibles, 4. responsiveness, 5. empathy. , that are measured by 22 statements valued on a 7-grade Likert scale. The original and the modified SERVQUAL has become a widely used technique for assessing service quality (used by dentistry, hotel management, airlines, banks, IT services, electricity services, higher education, etc.). The original questionnaire lists both positive and negative statements in order to capture the respondents' attention, thus the grades given to negative statements have to be re-coded. However, to save time, questionnaires containing only positive statements have become increasingly popular, and Parasuraman, Zeithaml, and Malhotra (1985b) also used a scale of only 5 values instead of the original 7-point scale, when assessing electronic services. Altogether the 22 statements are to be assessed according to the importance of the aspect for the customer, and according to the quality of the actual achievement of the aspect.

In tourism research the most popular primary research tools are surveys and observations. Personal questionnaires are generally used for assessing customer satisfaction in spite of their expensive and time-consuming character, because questionnaires can provide excellent quality information (both qualitative and quantitative data) for the service provider, and the responsiveness of the surveyed customers is usually high. This is the reason why hotels employ Guest Relation Managers, whose task includes collecting feedback from guests of the hotel (Karakasné Morvay, 2014). Besides customer questionnaires the questionnaire-based surveying of staff is also important (to gain information about their level of satisfaction, and accumulated experience), that can be used for improving service quality and increasing customer satisfaction and customer loyalty. Surveys should be conducted regularly for discovering emerging changes.

Assessment of customer satisfaction has been widely researched and several empirical results are known in the relevant literature. The present research could not provide a detailed overview, but for the sake of comparison an earlier study of Bacsi, Kovács, and Lőke (2012) should be mentioned here, because this presents the results of a survey done in 2010 about customer satisfaction in some spa town - including Hévíz - in Western Hungary. This survey focused on the services available in the town, not only on those provided by the spa, but included medical treatments, bathing facilities and fitness and food services as well. 


\section{OBJECTIVES AND METHODS}

The location of the primary analysis was the St. Andrew Hospital for Rheumatic Diseases in the town of Hévíz (in Western Hungary). The hospital is owned in 100\% in state ownership.

Hévíz, the second most favoured tourist destinations of Hungary according to guest nights spent in commercial accommodation, possesses a unique natural attraction, the thermal lake of Hévíz, $44000 \mathrm{~m}^{2}$ surface, with medical mud and healing water. The Saint Andrew Hospital for Rheumatic Diseases is the caretaker of the lake and of the surrounding nature reserve area of $620000 \mathrm{~m}^{2}$. At the depth of $38 \mathrm{~m}$ in the bottom there is a cave where several hot and cold springs emerge from underground, rich in minerals, and they feed the lake, resulting in a water temperature of $24-38^{\circ} \mathrm{C}$ depending on the weather. Therefore the thermal lake is suitable for bathing throughout the year. The calcium-magnesium-hydrogen carbonate content of the water makes it beneficial for joint disorders and rheumatic diseases. A unique feature of the lake is the fact that the patients or guests can swim in it, or bathe in a fully vertical body position.

The first bathing establishment was built at the lake at the end of the 18th century by the Festetics family, and this was the predecessor of the Saint Andrew Hospital of Rheumatic Diseases, founded in 1952. This establishment facilitates the bathing in the medicinal water of the thermal lake, and, in addition, provides the possibility of bathing in the intramural pools filled up with the healing water flowing here through pipelines from the lake. These pools are called Pool Bath. The typical customers of the thermal lake are guests, coming on their own, while the majority of customers at the Pool Bath are medical tourists, i.e. patients suffering from a medical condition, supported by the National Health Insurance Fund (NHIF - the Hungarian acronym is OEP). However, there is an overlap between the customers of the two locations, as the thermal lake can also be accessed by tickets supported by the NHIF. This creates a duality for the service provider: they have to harmonise the demands of two distinct target groups, the diseased medical tourist and the guest more interested in recreation and enjoyment.

In order to provide treatments in the thermal lake and the spa for people of moderate incomes, Hungarian citizens, diagnosed with diseases by specialised medical practitioners, are entitled to purchase 15 spa tickets a year at discounted prices, supported by the National Health Insurance Fund (Tab. 1). 
Table 1 Spa ticket types and prices in 2018 at the St. Andrew Hospital for Rheumatic diseases

\begin{tabular}{|c|c|c|}
\hline Ticket Type & Hévíz Thermal Lake & Pool Bath \\
\hline Normal full price ticket & 3000 HUF (3-hour stay) & 2000 HUF (3-hour stay) \\
\hline Senior ticket (above 60 ys) & 2500 HUF (3-hour stay) & 1800 HUF \\
\hline Student ticket (with valid student card) & 2500 HUF (3-hour stay) & 1500 HUF \\
\hline Discounted spa ticket supported by the NHIF & 1100 HUF (2-hour stay) & 700 HUF \\
\hline
\end{tabular}

Source: Hévíz Medicinal Spa and Saint Andrew Hospital for Rheumatic Diseases. (2018). Services. (www.spaheviz.hu/en/saint_andrew/services/and www.spaheviz.hu/en/tofurdo/services/)

The primary research method was the direct structured survey method, to allow many varied questions and achieve a large sample size at the location of the service provision (Keller, 2010), and working with an interviewer in person provides high response rates.

The survey was conducted between 27 February and 31 March 2017. The survey sample was divided to two parts: $50 \%$ was surveyed in the Pool Bath and 50\% in the thermal lake, questioning altogether 300 customers - patients and guests. The questionnaires were administered by 13 interviewers - university students specialised in tourism studies. The questionnaires contained 5- point Likert scales easily understandable for respondents. The questionnaires contained the questions developed by Parasuraman et al. (1985a) for measuring perceived service quality, adapted to the spa service provider. The questionnaire used in the Pool Bath was in $96 \%$ identical to the one used in the thermal lake, to facilitate comparisons of the two locations. The $4 \%$ difference was the question: "Staff is punctual and keep the treatment schedule" which was asked in the Pool Bath regarding its quality and importance aspect on a 5-point Likert scale, but was not relevant, therefore not included in the questionnaire used in the thermal lake.

The method has received considerable criticisms since the ' 90 -es, including the mission of the double question scale, which would considerably increase the time required for completing the survey (Veres, 2009). The double scale, though time consuming, is useful in identifying the critical points of the service, therefore the present research included it in the questionnaires. The questions referring to the components of the service - using a 5-point Likert scale - asked about the performance of the Hévíz Spa, and then about the importance of the components, and not about the expectations of the customers, as in the original model. The 5-point scale was also used instead of the original 7-point e Likert scale by Parasuraman et al. (1985a) in a service sector analysis. A Hungarian researcher Veres (2009) also questions the suitability of a 7-grade Likert scale. To minimise first-order error the performance of the service provider and the importance of the various components are asked separately in the 
questionnaire. Negative statements were omitted, because Veres (2009) finds it often "disturbing, and leading to distorted answers" in Hungarian surveys. The original SERVQUAL method used a mixture of positive and negative statements to force the respondents to respond with care. In the present survey the statements of the five service dimensions - tangibles, responsiveness, reliability, assurance, empathy - were rotated in the questionnaire, to maintain respondents' awareness. The questions related to customer satisfaction were also assessed by a 5-point Likert scale. The last few questions of the questionnaire referred to the respondents' gender, age, permanent residence, highest educational attainment, and job. The survey was analysed by the statistical software SPSS 22 . The statistical analysis of the survey results was done by descriptive statistics, frequency analyses, analyses of variance (ANOVA), correlation analyses and cross-table analyses. The evaluation followed the methodology described in Sajtos and Mitev (2007), Hofmeister Tóth, Simon, and Sajtos (2003) and Malhotra (2002). The main features of the primary research are summed up in Tab. 2.

Table 2 Summary of the features of primary research

\begin{tabular}{|c|c|}
\hline ASPECT & PRIMARY RESEARCH OF SPA SATISFACTION \\
\hline $\begin{array}{l}\text { Method of primary } \\
\text { quantitative data collection }\end{array}$ & $\begin{array}{l}\text { In person questionnaire-based survey by random sampling at the location of } \\
\text { service provision. }\end{array}$ \\
\hline Working with interviewers & $\begin{array}{l}83 \% \text { of questionnaires administrated by student interviewers, } 17 \% \\
\text { administered by the leading researcher. }\end{array}$ \\
\hline Location of survey & $\begin{array}{l}\text { Two locations within the Hévíz Spa and St. Andrew Hospital for Rheumatic } \\
\text { Diseases: } 50 \% \text { in the Pool Bath, and 50\% at the Hévíz Thermal Lake. }\end{array}$ \\
\hline Range of surveyed populations & $\begin{array}{l}\text { Hungarian customers using the services of the Hévíz Spa: } \\
45.4 \% \text { of them are guests, and } \\
54.5 \% \text { of them are patients, medical tourists supported by the National } \\
\text { Health Insurance Fund. }\end{array}$ \\
\hline Date of data collection & 27 February to 31 March, 2017. \\
\hline Response rate & In Pool Bath 1:1, At thermal lake $3: 1$ \\
\hline $\begin{array}{l}\text { Number of evaluated } \\
\text { questionnaires }\end{array}$ & 300 \\
\hline
\end{tabular}

Source: Authors' own construction

\section{RESULTS}

\section{The characteristics of the sample, features of respondents}

The sample contained 300 persons, selected from among the customers of the Hévíz Spa according to the methodology described in the section Materials and Methods. The main 
customer segment of the Hévíz Spa specialised in treating locomotor and rheumatic diseases is the elderly population, and this is reflected in the survey sample. Altogether $51.5 \%$ of the respondents is between 51 and 70 years of age, 19.7\% of them are between 36 and 50, and $15.4 \%$ is above 70 (Tab. 3). The remaining $13.4 \%$ falls into the age categories of $26-35,19-$ 25, and 14-18 (1 person) (One female respondent refused to answer the question about her age.)

Table 3 The sample structure according to gender and age category

\begin{tabular}{|c|r|r|r|r|}
\hline Age (years) & Male & \multicolumn{1}{|c|}{ Female } & \multicolumn{1}{|c|}{ Total } & \multicolumn{1}{c|}{ Proportion } \\
\hline $\mathbf{1 4 - 1 8}$ & 0 & 1 & 1 & $0.3 \%$ \\
\hline $\mathbf{1 9 - 2 5}$ & 5 & 6 & 11 & $3.7 \%$ \\
\hline $\mathbf{2 6 - 3 5}$ & 10 & 18 & 28 & $9.4 \%$ \\
\hline $\mathbf{3 6 - 5 0}$ & 28 & 31 & 59 & $19.7 \%$ \\
\hline $\mathbf{5 1 - 7 0}$ & 59 & 95 & 154 & $51.5 \%$ \\
\hline above 70 & 19 & 27 & 46 & $15.4 \%$ \\
\hline Total & 121 & 178 & 299 & $100.0 \%$ \\
\hline
\end{tabular}

Source: Authors' own results

The gender structure of the sample shows a less than $1 \%$ divergence from the customer gender structure of the Pool Bath in 2016, therefore it properly represents the gender structure of the customer population. In the Pool Bath $38.7 \%$ of the respondents were male and $61.3 \%$ female (Tab. 4). In the thermal lake the majority of the customers were female, the proportion was $42 \%$ male and $58 \%$ female guests. The total sample was made up of 121 men $(40.3 \%)$ and 179 women $(59.7 \%)$.

Table 4 Gender distribution of the respondents at the two locations

\begin{tabular}{|l|r|r|}
\hline \multicolumn{1}{|c|}{ Gender distribution } & \multicolumn{1}{|c|}{ Male } & \multicolumn{1}{c|}{ Female } \\
\hline Pool Bath, data from 2016 & $38.0 \%$ & $62.0 \%$ \\
\hline Pool Bath ( sample size: $\mathbf{n = 1 5 0 )}$ in current primary research & $38.7 \%$ & $61.3 \%$ \\
\hline Hévíz thermal lake ( sample size: $\mathbf{n = 1 5 0 )}$ in current primary research & $42.0 \%$ & $58.0 \%$ \\
\hline Respondents ( sample size: $\mathbf{n = 3 0 0 )}$ in current primary research & $40.3 \%$ & $59.7 \%$ \\
\hline
\end{tabular}

Source: Authors' own results

The largest segment of respondents according to educational attainment were those possessing a university degree $(38.67 \%)$ and those completing secondary school with matriculation (37.67\%), 14\% completed a vocational secondary school and 3\% has completed the 8 years of primary school, while 20 persons refused to answer. 
Due to the fact, that the majority of customers are elderly, nearly half $(48 \%)$ of the respondents are retired. Somewhat less is the proportion of employees, self-employed entrepreneurs, managers, and the smallest group is students.

\section{Comparison of the customers of the Hévíz Thermal Lake and of the Pool Bath}

The next research question was to check whether the survey would justify the expectation that the majority of the customers of the Pool Bath are patients using the spa services by NHIF support, while the majority of the customers in the Thermal Lake are guests, and not NHIFsupported patients. The null-hypothesis is that the proportion of customers supported by NHIF is the same in the Pool Bath and in the thermal lake. The managers of the Spa do not have exact information about the proportion of the NHIF-supported patients among the customers, only a subjective expectation, that the proportion of the NHIF-supported patients is higher in the Pool Bath than in the thermal lake. The tests was aimed at finding out more precise information about this feature.

A cross-table analysis was used to evaluate 290 responses, as 10 persons gave no answers to the question whether they use the spa services by NHIF support or not. The $79.1 \%$ of the customers in the intramural Pool Bath are patients supported by NHIF and 20.9\% are guests without NHIF support, while in the Thermal Lake the proportions are just the opposite, $28.9 \%$ are supported by NHIF and $71.1 \%$ are not supported by NHIF (Fig. 1). The proportion of the NHIF-supported customers in the whole sample is $54.5 \%$ and the proportion of those paying the full price without NHIF support is $45.5 \%$ (buying a full price, or senior, or student spa ticket).

Figure 1 Cross-table analysis of respondents using the service locations (Pool Bath or Thermal lake) and using normal spa tickets or discounted tickets supported by NHIF

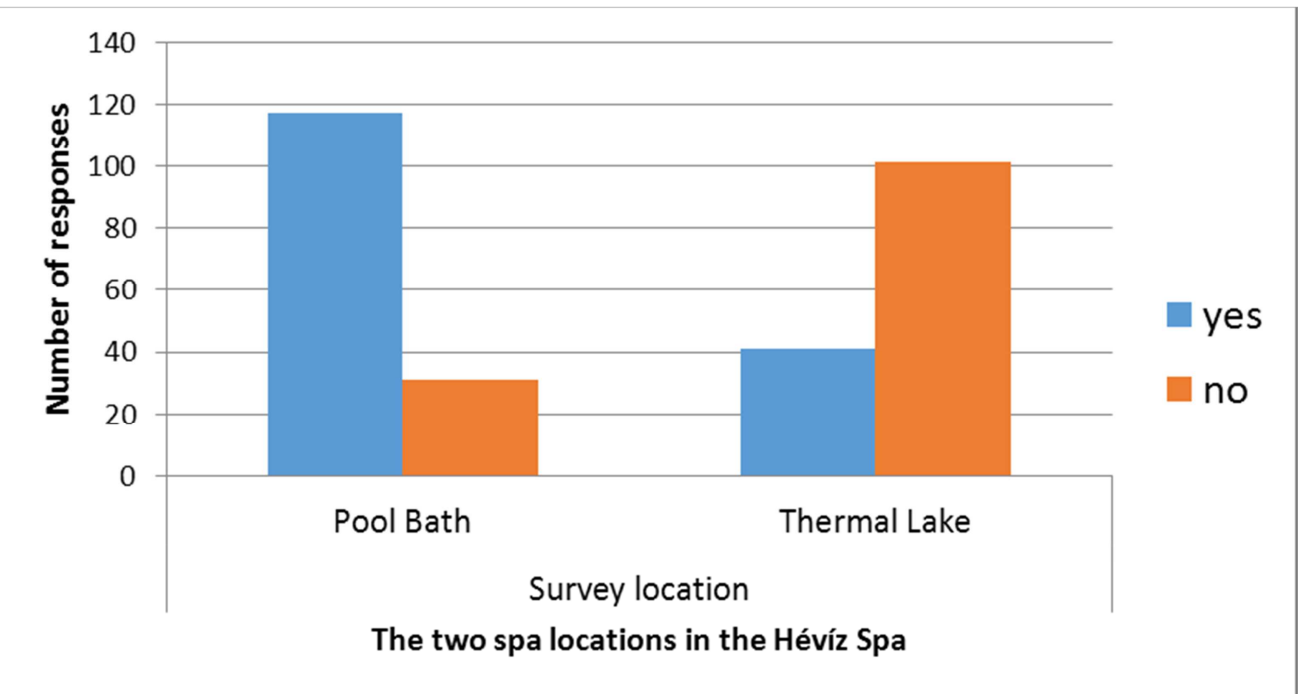

Source: Authors' own research 
The results of the cross-table analysis show that the null hypothesis should be rejected. This means that there is a difference between the two service locations - the Pool Bath and the Thermal Lake - in the aspect of using the spa with or without NHIF support. The significant majority of the Pool Bath visitors use the spa with NHIF support, while most of the customers going to the Thermal Lake have no support from NHIF. This is the reason why they are called "guests", while the customers of the Pool Bath are called "patients". The indicator is symmetric, i.e., if the role of two variables is changed to the opposite, the test shows a significant difference in the location of service usage between NHIF-supported customers and those not having NHIF support. The Pearson-Chi-square test shows a significant relationship between NHIF support and service location, the results are reliable according to the contingency test $\left(\chi^{2}=73.586 ; \mathrm{df}=1, \mathrm{p}=0.000\right)$. The value of $\mathrm{Phi}=0.504$ shows a medium level significant correlation between the two variables, which supports our preliminary expectations.

The customers' gender distribution, i.e. the proportions of men and women are about the same among NHIF-supported patients and non-NHIF-supported guests (Tab. 5). The crosstable analysis found no significant difference between men and women with regard to NHIFsupport $\left(\chi^{2}=0.07 ; \mathrm{df}=1 ; \mathrm{p}=0.934\right)$, the difference is only $0.5 \%$ between men and women in this respect.

Table 5 The distribution of the sample by gender and NHIF support

\begin{tabular}{|l|r|r|r|}
\hline \multirow{2}{*}{ Gender } & \multicolumn{2}{|c|}{ Do you have NHIF support? } & \multicolumn{1}{c|}{ Total } \\
\cline { 2 - 3 } & \multicolumn{2}{|c|}{ Yes } & \multicolumn{2}{c|}{ No } & \\
\hline Male & $54.8 \%$ & $45.2 \%$ & $100.0 \%$ \\
\hline Female & $54.3 \%$ & $45.7 \%$ & $100.0 \%$ \\
\hline Total & $54.5 \%$ & $45.5 \%$ & $100.0 \%$ \\
\hline
\end{tabular}

Source: Authors' own results

The proportion of NHIF-supported patients is $54.8 \%$ among men, and $54.3 \%$ among women. Altogether, $54.4 \%$ of all customers use the spa services with NHIF support, and less than half of them (45.5\%) pay for their own spa ticket without NHIF support.

\section{Testing the importance of service quality and quality components}

According to the SERVQUAL method, adapted for the spa services, the performance of the quality factors was measured by a 5-point Likert-scale. The average of the quality 
performance was measured to be 4.640 , with 0.3782 standard deviation, which indicates a very high quality achievement by the service provider.

In spite of its time-consuming character, and the criticisms against the SERVQUAL model, we considered it reasonable to survey the customers' opinions about the importance of various quality components, to reveal if there is any difference between the two customer groups (patients and guests) regarding the importance of these components. Respondents rated the importance of these components rather high, average scores turned out to be between 4.43 and 4.91 on a 5-point scale. For most of the quality components the average importance-scores were higher for NHIP-supported patients. The guests gave higher scores only in two aspects, i.e.: the whole area of the service location should be clean and hygienic (mean score $=4.884$, the most important factor for guests), and the establishment should provide space suitable for relaxation with resting chairs inside, and park and walking path outside.

Analysis of variance was applied to test the difference between the two target groups in the assessment of importance. The null-hypothesis was that the average scores do not differ between the two customer groups. The Levene-test showed that homogeneity of standard deviations was true only for 5 of the 23 importance components, the rest had to be omitted from further analysis. The analysis of variance procedure found no difference for these 5 factors between guests and visitors, therefore the null-hypothesis cannot be rejected, the guests' opinion about the importance of these factors does not differ significantly from the patients' opinions.

A ranking of importance was set up by the average scores, which showed that for NHIFsupported patients the tangible components are the least important (all the 5 tangible factors were given scores putting them at the last 6 places in the list). According to the guests' scores 3 of the last 6 items in the list are tangible components, but the remaining 2 tangible components are ranked at around the top of the list (6th and 7th place, with an average score of 4.762 for both). These two components were: the establishment provides space suitable for relaxation with resting chairs inside, and park and walking path outside, and the staff looks clean and orderly. For NHIF-supported patients the most highly ranked factor by importance were: 1. Staff is well trained, competent (4.971) 2. Staff is punctual and keep the treatment schedule (4.896). 3. Services are performed perfectly with no errors (4.867), and these factors well describe what the patients consider to be the most important tasks of the service provider. Regarding the importance ranking the expectations of the two target groups, patients and guests, seem to differ considerably. 
The 'patients' and 'guests' different rankings by importance of service quality components are shown in Fig. 2 and 3. The two most important factors for NHIP-supported patients were reliability and assurance (with only a very slight difference between the two), followed by empathy. Their expectations reflected in the importance scores are very high for all the four human components, while they are much less demanding in the tangible components. For guests the first three components are assurance, empathy, and reliability, all with aboveaverage importance scores. The two least important components are responsiveness and tangible components for both target groups. It is interesting to note, that for patients the responsiveness component scored above-average, while for guests it is less than the average.

Figure 2 The difference of the average importance of various service quality components from the total average importance, by the NHIF-supported patients, on a 1-5 scale

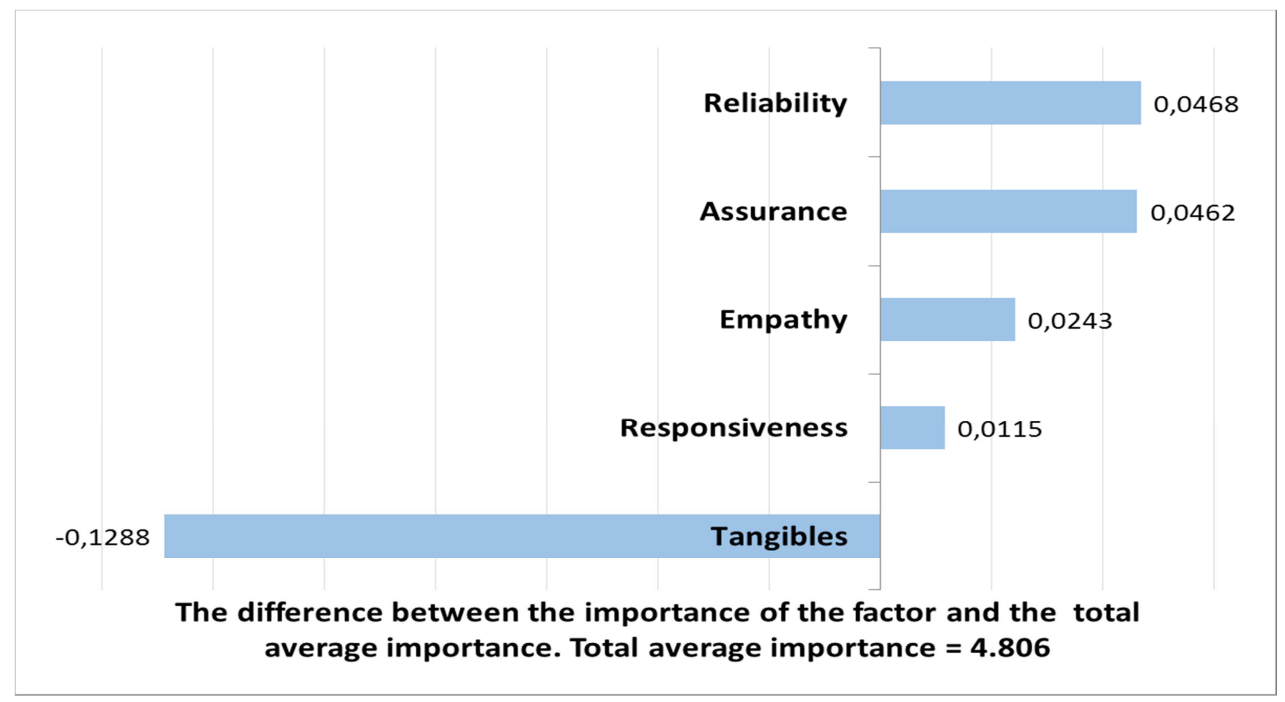

Source: Authors' own results

Figure 3 The difference of the average importance of various service quality components from the total average importance, by the non-NHIF-supported guests, on a 1-5 scale

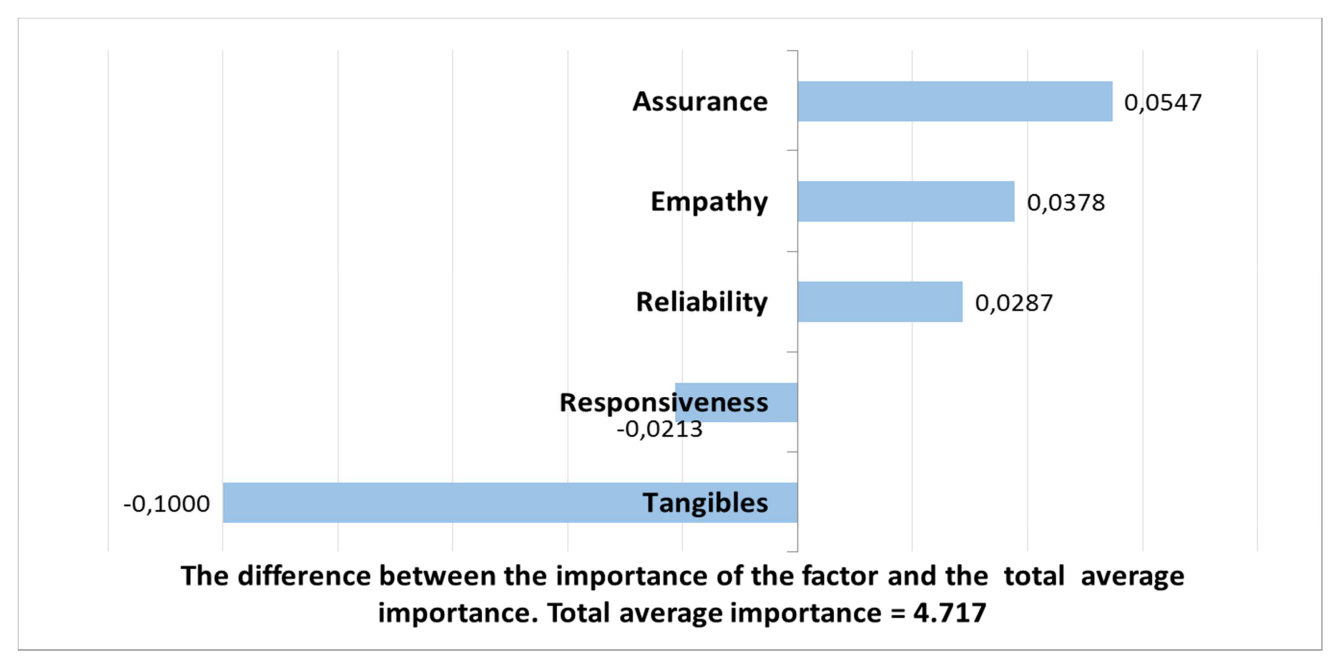

Source: Authors' own results 
The graphical presentation of the quality achievement and the quality importance reflects the strategic competitive advantage of the service provider, that determine the level of customer satisfaction (Hofmeister Tóth et al., 2003). These competitive advantages are the components, that are considered important and the service provider performs well in them, as is shown in the upper right quarter of Fig. 4 and 5. The good news for the service provider is that more than half of the assessed factors belong to this group. The further improvement of these factors is not urgent, but an improvement in them can considerably increase the overall level of customer satisfaction. For NHIF-supported patients these factors of competitive advantage includes several components of professional competence, e.g: staff is well trained and competent; staff is punctual and keeps the planned schedule of treatments, the staff of the spa show responsiveness, services are provided perfectly with no errors, etc. For guests the factors of competitive advantage also include: staff is well trained and competent; and further factors are the services provided at the treatments are personalised; the staff looks clean and orderly; staff is at their place and always available, etc.

The components located at the lower right quarter of the figure are not important but well performing factors, therefore maintaining their good performance is also important. For both target groups this category includes: the staff and the management behave politely, and the staff is friendly. In addition, for NHIF-supported patients the component spa staff looks clean and orderly also belong to this category. Non-NHIF-supported guests list two additional factors here: the staff cares about the service-related problems of the guests/patients and tries to solve them; and the staff generates trust and confidence.

The lower left quarter is the place of service factors not important and badly performed. These factors should be improved, but their development is not very urgent. These are socalled necessary conditions or endowments, whose improvement would not considerably raise consumer satisfaction (Hofmeister Tóth et al., 2003). For NHIF-supported patients these necessary conditions include: the buildings, outer and internal space of the spa are aesthetically pleasant; the spa is well equipped with up-to-date tools; the materials providing information (booklets and brochures, boards, notices) are easy to read and nicely designed; the establishment provides space suitable for relaxation with resting chairs inside, and park and walking path outside; the staff is an excellent source of information about the services of the spa. 
Figure 4 The opinion of the NHIF-supported patients of Hévíz Spa about the level of achievement and the importance of quality components

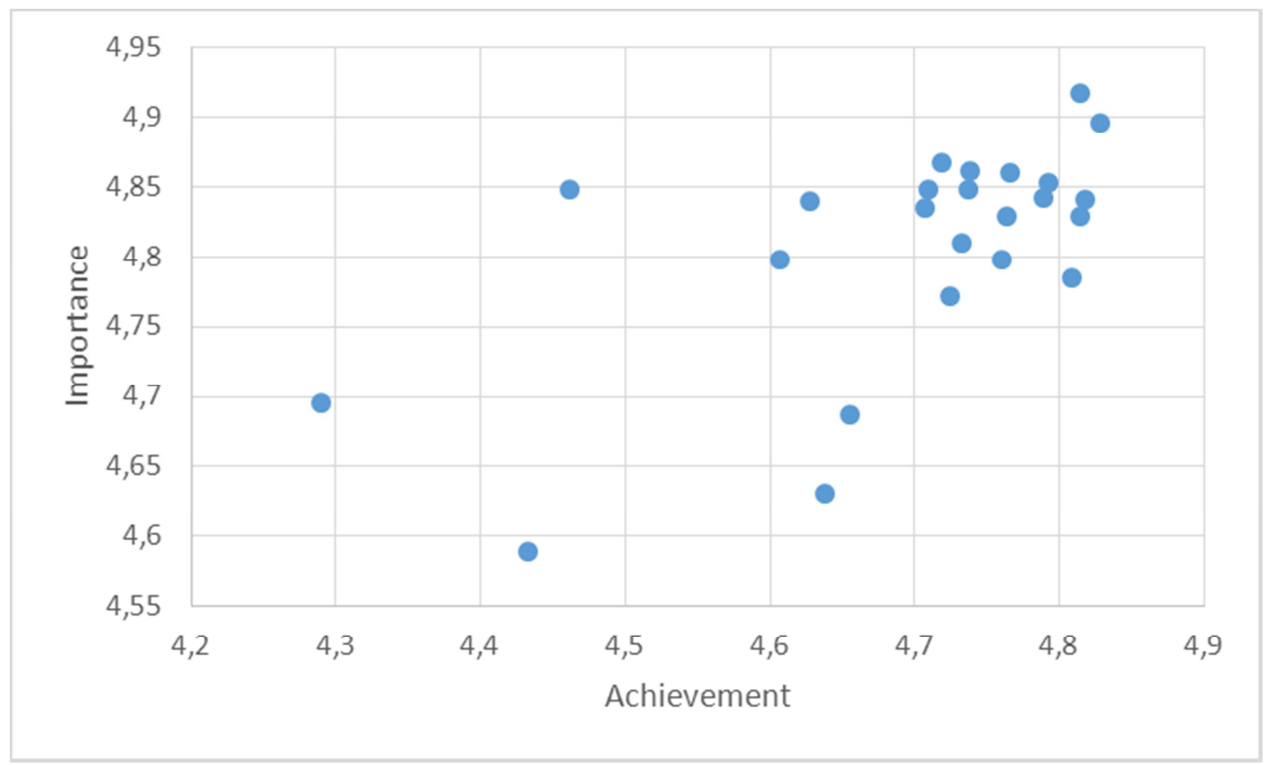

Source: Authors' own results

Figure 5 The opinion of the non-NHIF-supported guests of Hévíz Spa about the level of achievement and the importance of quality components

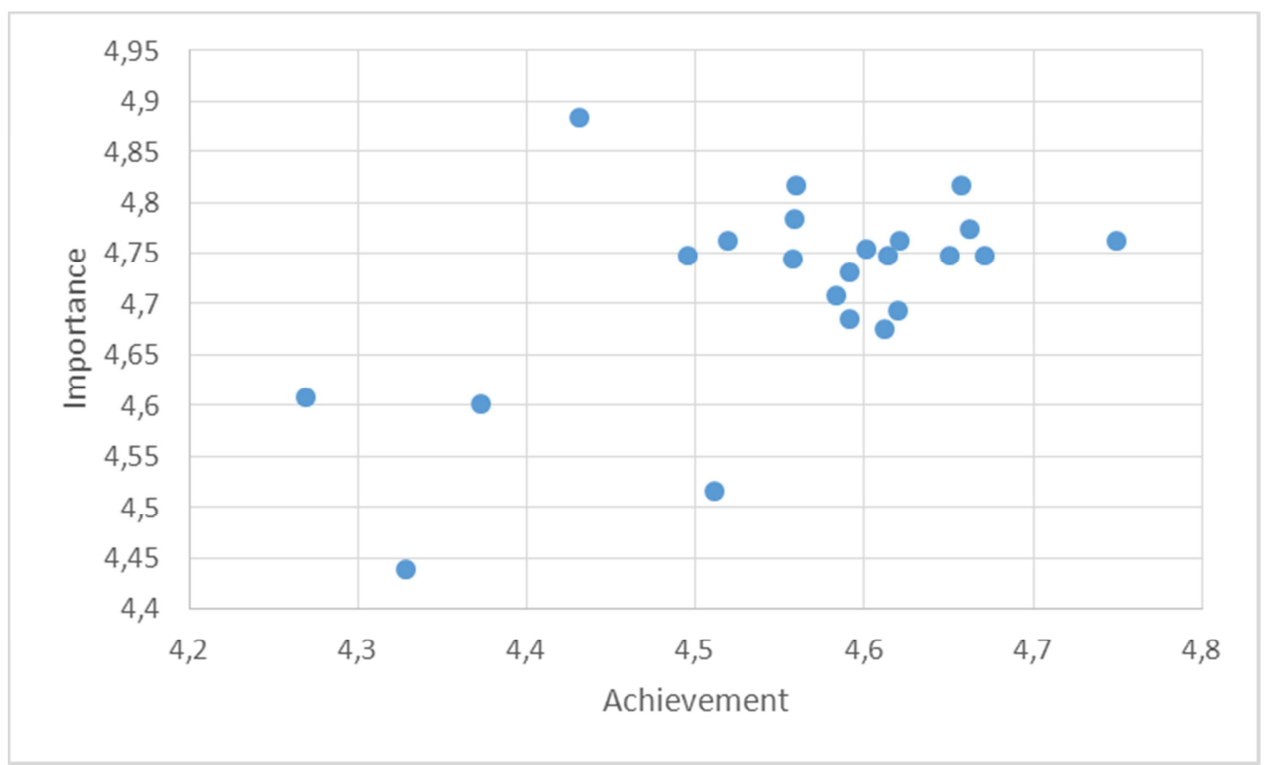

Source: Authors' own results

These necessary conditions are the same for guests and for patients, with one exception. This exception is the component the establishment provides space suitable for relaxation with resting chairs inside, and park and walking path outside. This component is a necessary condition for patients, while it is ranked in the upper right category of competitive advantages for guests.

The upper left quarter of the chart - i.e. the important, but not very well performing components - contain the factors that should be urgently improved. These poorly performing, 
but very important factors would considerably increase customer satisfaction, and then they could become competitive advantage factors. For NHIF-supported patients two factors (the whole area of the service location is clean and hygienic; and the spa provides personalised care for the patients according to their individual disease needs) and for non-NHIF-supported guests three factors (the guest feels safe and secure at the service provider; the whole area of the service location is clean and hygienic; services are provided perfectly with no errors) belong to this category (Tab. 6 and 7). These results can be useful for the service provider in planning the quality improvement tasks for the Pool Bath and the Thermal Lake, with respect to the different expectations of the two target groups.

Table 6 The quality factors grouped into the four quarters, by the NHIF-supported patients' opinions

\begin{tabular}{|c|c|}
\hline $\begin{array}{l}\text { TO BE IMPROVED URGENTLY } \\
\text { 1. The whole area of the service location is clean } \\
\text { and hygienic } \\
\text { 2. The spa provides personalised care for the } \\
\text { patients according to their individual disease } \\
\text { needs }\end{array}$ & $\begin{array}{l}\text { COMPETITIVE ADVANTAGES } \\
\text { 1. The staff of the spa show responsiveness. } \\
\text { 2. Staff responds quickly to the requests of } \\
\text { guests/patients. } \\
\text { 3. Staff is punctual and keeps the planned } \\
\text { schedule of treatments. } \\
\text { 4. Services are provided perfectly with no errors. } \\
\text { 5. Staff works quickly and efficiently. } \\
\text { 6. Staff is reliable and they really care about } \\
\text { customers. } \\
\text { 7. The staff cares about the service-related } \\
\text { problems of the guests/patients and tries to } \\
\text { solve them. } \\
\text { 8. The staff is at their place and always available. } \\
\text { 9. The customer feels safe and secure at the } \\
\text { service provider. } \\
\text { 10. The staff answers the customers' questions. } \\
\text { 11. Staff is well trained and competent. } \\
\text { 12. The staff is an excellent source of information } \\
\text { about the services of the spa. } \\
\text { 13. Staff generates trust and confidence. } \\
\text { 14. The spa provides personalised care for the } \\
\text { patients according to their individual disease } \\
\text { needs. }\end{array}$ \\
\hline $\begin{array}{l}\text { NECESSARY CONDITIONS, IMPROVEMENT } \\
\text { IS NOT URGENT } \\
\text { 1. The buildings, outer and internal space of the } \\
\text { spa are aesthetically pleasant. } \\
\text { 2. The spa is well equipped with up-to-date tools } \\
\text { 3. The materials providing information (booklets } \\
\text { and brochures, boards, notices) are easy to } \\
\text { read and nicely designed } \\
\text { 4. The establishment provides space suitable for } \\
\text { relaxation with resting chairs inside, and park } \\
\text { and walking path outside } \\
\text { 5. The staff is an excellent source of information } \\
\text { about the services of the spa. }\end{array}$ & $\begin{array}{l}\text { TO BE MAINTAINED AT THE CURREN } \\
\text { LEVEL } \\
\text { 1. The staff looks clean and orderly. } \\
\text { 2. Staff and management behave politely. } \\
\text { 3. The staff is friendly. }\end{array}$ \\
\hline
\end{tabular}


Table 7 The quality factors grouped into the four quarters, by the non-NHIF-supported guests' opinions

\begin{tabular}{|c|c|}
\hline $\begin{array}{l}\text { TO BE IMPROVED URGENTLY } \\
\text { 1. The customer feels safe and secure at the } \\
\text { service provider } \\
\text { 2. The whole area of the service location is } \\
\text { clean and hygienic; } \\
\text { 3. Services are provided perfectly with no } \\
\text { errors }\end{array}$ & $\begin{array}{l}\text { COMPETITIVE ADVANTAGES } \\
\text { 1. The staff looks clean and orderly. } \\
\text { 2. The establishment provides space suitable } \\
\text { for relaxation with resting chairs inside, and } \\
\text { park and walking path outside. } \\
\text { 3. The staff of the spa show responsiveness. } \\
\text { 4. Staff responds quickly to the requests of } \\
\text { guests/patients } \\
\text { 5. Staff works quickly and efficiently. } \\
\text { 6. Staff is reliable and they really care about } \\
\text { customers. } \\
\text { 7. The staff is at their place and always } \\
\text { available. } \\
\text { 8. The staff answers the customers' questions. } \\
\text { 9. Staff is well trained and competent. } \\
\text { 10. The staff is an excellent source of } \\
\text { information about the services of the spa. } \\
\text { 11. The services provided at the treatments are } \\
\text { personalised. } \\
\text { 12. the spa provides personalised care for the } \\
\text { patients according to their individual disease } \\
\text { needs. }\end{array}$ \\
\hline $\begin{array}{l}\text { NECESSARY CONDITIONS, } \\
\text { IMPROVEMENT IS NOT URGENT } \\
\text { 1. The buildings, outer and internal space of } \\
\text { the spa are aesthetically pleasant. } \\
\text { 2. The spa is well equipped with up-to-date } \\
\text { tools } \\
\text { 3. The materials providing information } \\
\text { (booklets and brochures, boards, notices) are } \\
\text { easy to read and nicely designed. } \\
\text { 4. The staff is an excellent source of } \\
\text { information about the services of the spa. }\end{array}$ & $\begin{array}{l}\text { TO BE MAINTAINED AT THE CURRENT } \\
\text { LEVEL } \\
\text { 1. Staff and management behave politely. } \\
\text { 2. The staff cares about the service-related } \\
\text { problems of the guests/patients and tries to } \\
\text { solve them. } \\
\text { 3. Staff generates trust and confidence. } \\
\text { 4. Staff is friendly. }\end{array}$ \\
\hline
\end{tabular}

Source: Authors' own results

\section{Customer satisfaction}

Customers were asked to evaluate their level of satisfaction on a 5-grade Likert-scale about the services provided by the Hévíz Spa.

The relevant literature suggests that there should be a positive correlation between service quality and level of satisfaction with the service. To test this relationship the scores given to the service quality factors were compared to the scores the respondents gave to the question "to what extent are you satisfied altogether with the spa" (1-5 grade Likert scale). Results showed a medium positive correlation at $1 \%$ level of significance (Pearsons correlation coefficient $=0.633$ ) between quality and level of satisfaction. The respondents ranking the 
performance of the spa higher were found to be more satisfied with spa services, as has been proven in many previous research publications (Al-alak \& EL-refae, 2012; Kozmáné Csirmaz, 2017).

Our hypothesis was that the level of satisfaction with services is different for guests and for patients. This hypothesis was tested at both service locations, the Pool Bath and the Thermal Lake alike, because the Pool Bath has mainly a medical treatment atmosphere while the Thermal Lake is a typical tourist service location. Multiple analysis of variance was applied in testing the following three null-hyptheses, after the necessary requirements for applying the methods were checked:

1. The level of satisfaction does not significantly differ between guests and NHIF-supported patients.

2. The level of satisfaction does not significantly differ between the customers of the Pool Bath and the of the Thermal Lake.

3. The interaction of the service location and the customer status (guest or patient) does not influence the level of customer satisfaction.

The NHIF-supported patients showed higher level of satisfaction at both locations, than guests. The level of patient satisfaction scored 4.479 in the Pool Bath and 4.585 in the Thermal Lake, while the scores of guest satisfaction were only 4.065 in the Pool Bath and 4.347 in the Thermal Lake. Both customer groups were more satisfied with the services of the Thermal Lake than of the Pool Bath.

As Table 8 presents, the customer status (guest or patient) significantly influences the level of satisfaction (a 1\% level of significance). Therefore the first null-hypothesis is rejected. The second and third null-hypotheses, however, cannot be rejected, because the effect of the service location is not significant (sig. $=0.056$ in Tab. 8), neither the impact of the interaction of location and customer status (sig. $=0.387$ ), i.e., these factors do not influence the level of customer satisfaction. Customer status, i.e. whether customers use the spa services with support from the NHIF (patients) or without it (guests), has a significant impact on the level of satisfaction, but this impact is not too strong, as is shown by the value Eta-square of 0.035 (which is much smaller than the theoretical high value of 1). The coefficient of determination is very low, $\mathrm{R}^{2}=0.037$, i.e. the customer status (patient or guest) is responsible only for $3.7 \%$ of the level of satisfaction. The overall average score of customer satisfaction is 4.369 (on a 5point scale), thus the customers are altogether quite satisfied with the services of the Hévíz Spa. 
Table 8 Multiple analysis of variance (dependent variable: "To what extent are you satisfied with the spa altogether?", independent variables: Location, and Customer status defined by the question "Are you a NHIF-supported customer?")

\begin{tabular}{|l|c|c|c|c|c|c|}
\hline \multicolumn{6}{|c|}{ Multiple Analysis of Variance: To what extent are you satisfied with the spa altogether? } \\
\hline & $\begin{array}{c}\text { Residual Sum } \\
\text { of Squares }\end{array}$ & $\begin{array}{c}\text { Degree of } \\
\text { freedom }\end{array}$ & $\begin{array}{c}\text { Mean Sum of } \\
\text { Squares }\end{array}$ & $\mathrm{F}$ & Sig. & $\begin{array}{c}\text { Partial Eta- } \\
\text { square }\end{array}$ \\
\hline Adjusted model & $5.906^{\mathrm{a}}$ & 3 & 1.969 & 3.612 & 0.014 & 0.037 \\
\hline Intercept & 4066.476 & 1 & 4066.476 & 7460.464 & 0 & 0.963 \\
\hline Location & 2.012 & 1 & 2.012 & 3.692 & 0.056 & 0.013 \\
\hline Customer status & 5.677 & 1 & 5.677 & 10.416 & 0.001 & 0.035 \\
\hline $\begin{array}{l}\text { Location } \\
\text { customer status }\end{array}$ & 0.409 & 1 & 0.409 & 0.751 & 0.387 & 0.003 \\
\hline
\end{tabular}

a: $\mathrm{R}^{2}=0.037$

Source: Authors' own results

The graphical presentation of the results shows clearly that the NHIF-supported patients are more satisfied than non-NHIF-supported guests at both service locations (Fig. 6).

Figure 6 The overall level of customer satisfaction at the Hévíz Spa, by service location and customer target group

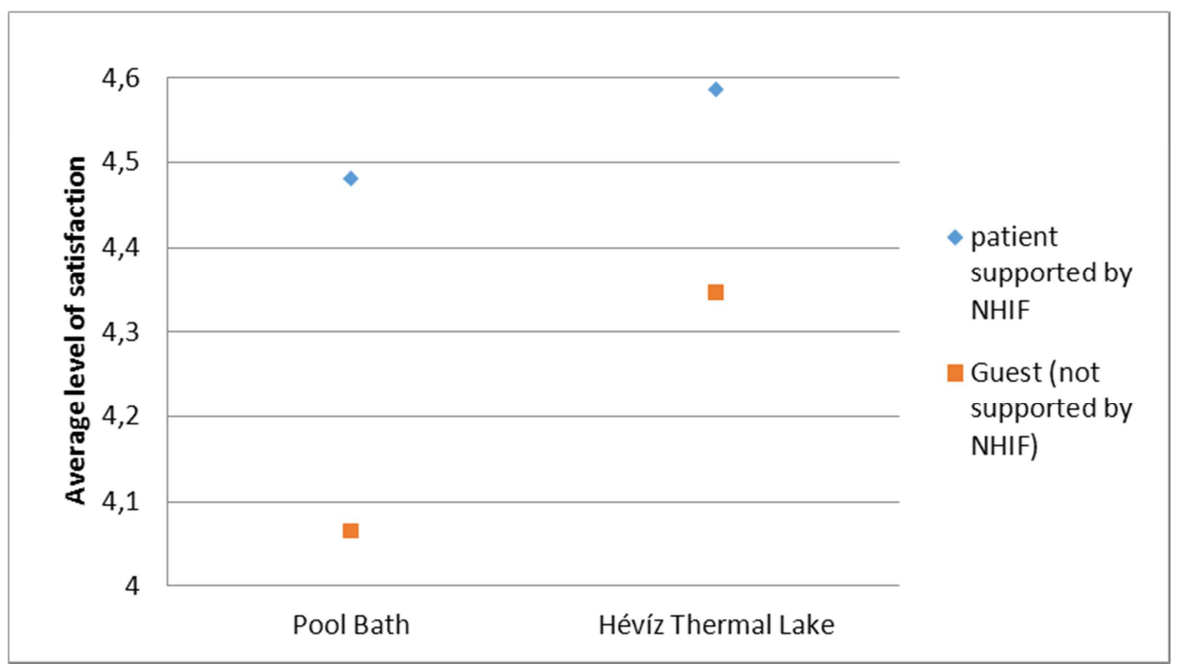

Source: Authors’ own results

\section{DISCUSSION AND CONCLUSION}

As Kotler and Keller (2012) state, a forward-looking company considers customer satisfaction not only a goal in itself, but an effective marketing tool, as well. The high quality service is a competitive advantage, contributing to the ability to retain customers and attract new ones. For a state-owned health institution working in the health tourism sector the benefits of positive word-of-mouth promotion by satisfied customers cannot be overestimated. 
As Bacsi et al. (2012) found in their survey, the spa visitors in Hévíz were mostly returning visitors (78.4\%) in 2010, whose main source of information was their former experience in the same spa. From among the services provided by the spa, customers ranked the medical treatments the highest, with a score of 4.53 followed by bathing (4.44) in a simple 5-point Likert-scale, indicating a rather high level of satisfaction with spa services. Similar or slightly lower levels of overall satisfaction were found in the present research (4.37), though the direct comparison is not reasonable, as range of evaluated components was much wider now.

The well-known positive linear relationship between quality and level of satisfaction was justified by the sample. Quality, as Veres (2009) notes, although a qualitative value judgement, can be well measured on a 1-5 grade Likert scale by the questionnaire about the performance of various service quality components defined by the SERVQUAL method adapted to spa service providers. As the analysis of variance proved, the customer status (i.e. being a guest or a patient) significantly influences the level of satisfaction. Patients are generally more satisfied both in the Pool Bath and in the Thermal Lake than guests. Surprisingly, the service location did not have any impact on the level of satisfaction. The high level of satisfaction is very valuable for the Hévíz Spa, because satisfied customers generate the positive image and fame of the service provider. Many studies - including Anderson (1985) - showed that customer satisfaction has a positive impact on the number of recommendations, and word-of-mouth promotion is strongest when customer satisfaction is very high or very low. Positive word-of-mouth promotion cannot be overestimated for stateowned health service providers because according to Hungarian legislation they are not allowed to promote their services.

Although the analysis of variance did not show any significant difference between patients and guests regarding the importance of quality components, but the ranking of the various components differ considerably. Guests, for example, considered tangible components more important, e.g. the spaces suitable for relaxation, and the staff's cleanliness and orderly looks were the 6th and 7th most important factors for them. For patients, however, tangible components were ranked at the bottom of the importance order.

The importance and the performance of various service quality components were plotted against each other to identify components creating comparative advantages, components requiring maintenance but not needing urgent intervention, components to be urgently improved for meeting customer expectations, and necessary conditions, which, even if improved, would not lead to significant increase in customer satisfaction. These give ideas for the service provider about what to develop in the Pool Bath and in the Thermal Lake. For the 
Hévíz Spa and St. Andrew Hospital for Rheumatic Diseases two components require urgent development for the NHIF-supported patients ( individual care for patients according their diseases, and cleanliness of the establishment) and three components for the non-NHIFsupported guests (cleanliness of the establishment, perfect service provision without errors, and the feeling of safety and security at the service provider).

The research proved without doubt, that the customers of the Pool Bath and those of the Thermal Lake significantly differ. The overwhelming majority of the customers in the Pool Bath are patients supported by the NHIF (79.1\%), while the customers in the Thermal Lake are mainly guests not supported by the NHIF (71.1\%). This relationship between customer type and service location is reasonably strong, therefore the service provider, seeking to improve service quality and customer satisfaction, should prioritise the guests' opinion when planning the development of the Thermal Lake services and focus on the patients' expectations when the development plans of the Pool Bath are considered.

\section{REFERENCES}

Al-alak, B. A., \& EL-refae, G. A. (2012). The Relationships between Service Quality, Satisfaction, and Behavioral Intentions of Malaysian Spa Center Customers. International Journal of Business and Social Science, 3(1), 198-205.

Anderson, E. (1998). Customer Satisfaction and Word of Mouth. Journal of Service Research, $1(1), 5-17$.

Bacsi, Z., Kovács, E., \& Lőke, Z. (2012). Spa successes and challenges in Transdanubia, Hungary - Results of a survey in three spa towns. Deturope, 4(1), 27-47.

Brown, W. S., Gummesson, E., Edvardsson, B., \& Gustavsson, B. (1991). Service Quality. Lexington Books. New York.

Doležalová, H., Pícha, K., Navrátil, J., Veselá, M., \& Švec, R. (2016). Perception of quality in decision making regarding purchase of organic food. Quality - Access to Success, 17(153), 86-91.

Filiatrault, P., Harvey, J., \& Chebat, J-C. (1996). Service quality and service productivity management practices. Industrial Marketing Management, 25(3), 243-255.

Friman, M. (2004). The structure of affective reactions to critical incidents. Journal of Economic Psychology, 25(3), 331-353.

Hévíz Medicinal Spa and Saint Andrew Hospital for Rheumatic Diseases. (2018). Services. Retrieved March 20, 2018, from www.spaheviz.hu/en/saint_andrew/services/ and www.spaheviz.hu/en/tofurdo/services/

Hofmeister Tóth, Á., Simon, J., \& Sajtos, L. (2003). Fogyasztói elégedettség [Customer satisfaction - In Hungarian]. Alinea Kiadó, Budapest.

Karakasné Morvay, K. (2014). A minőségfejlesztés és a vendégelégedettség összefüggései a hazai wellness szállodákban című doktori $\mathrm{PhD}$ értekezés [Relationship between quality assurance and customer satisfaction in wellness hotel sin Hungary. PhD Thesis - In Hungarian], SZIE Gödöllő. pp. 57-66, 192-205. Retrieved November 6, 2016, from https://szie.hu//file/tti/archivum/Karakasne_Klara_ertekezes.pdf

Keller, V. (2010). Az értékesítésösztönzés mint stratégia és taktika a kiskereskedelemben (Vizsgálatok kiskereskedők és fogyasztók körében a magyarországi felsőruházati termékek piacán). PhD értekezés [Sales promotion as strategy and tactics in retail 
(Analyses of retailers and consumers in the clothes market in Hungary. $\mathrm{PhD}$ Thesis in Hungarian.] Széchenyi István Egyetem, Győr. pp. 223. Retrieved February 12, 2017, from http://rgdi.sze.hu/files/Ertekezesek,\%20tezisek/Doktori_KV.pdf

Kenesei, Z., \& Kolos, K. (2007). Szolgáltatásmarketing és -mendzsment [Service marketing and management - In Hungarian]. Alinea Kiadó, Budapest. pp. 48, 128-138.

Ko, Y. J., \& Pastore, D. L. (2005). A hierarchical model of service quality for the recreational sport industry. Sport Marketing Quarterly, 14(2), 84-97.

Kotler, P., \& Keller, K. L. (2012). Marketing menedzsment [Marketing management Hungarian translation]. Akadémia Kiadó, Budapest. pp. 20, 149-155, 412.

Kotler, P. (1992). Marketing management elemzés, tervezés, végrehajtás és ellenőrzés. [Marketing management analysis, planning, implementation, monitoring - Hungarian translation]. Müszaki Könyvkiadó, Budapest. p. 407.

Kozmáné Csirmaz, É. (2017). A magyarországi rekreációs turizmus egyes szegmenseinek elemzése a fogyasztói elégedettség szempontjából címü $\mathrm{PhD}$ értekezés [The analysis of some segments of recreational tourism in Hungary from the aspect of consumer satisfaction..PhD Thesis - in Hungarian], Debreceni Egyetem, Gazdálkodástudományi Kar, Debrecen. p. 156. Retrieved March 5, 2018, from https://dea.lib.unideb.hu/dea/bitstream/handle/2437/236036/Kozmane_Csirmaz_Eva_e rtekezes_titkositott.pdf?sequence $=1 \&$ isAllowed $=y$

Malhotra, N. K. (2002). Marketingkutatás [Marketing research - Hungarian translation]. KJKKERSZÖV Jogi és Üzleti Kiadó Kft. Budapest.

Murray, K. B. (1991). A Test of Services Matketing Theory - Consumer Information Acquisition Activities. Journal of Marketing, 55(1), 10-25.

Parasuraman, A., Zeithaml, A. \& Berry, L. (1985a). A Conceptual Model of Service Quality and Its Implications for Future Research. Journal of Marketing, 49 (47). in: Swarbrooke, J. \& Horner, S. (2007). Consumer Behaviour in Tourism. Second edition. Published by Elsevier Ltd. Oxford, UK.

Parasuraman, A., Zeithaml, V. A. \& Malhotra, A. (1985b). E-S-QUAL: A Multiple-Item Scale for Assessing Electronic Service Quality. Journal of Service Research, 7(3) 18. in: Kenesei, Z. \& Kolos, K. (2007). Szolgáltatásmarketing és -menedzsment. Alinea Kiadó, Budapest. p. 140.

Rekettye, G. (1997). Az árak és a fogyasztói magatartás [Prices and consumer behaviour - In Hungarian]. Marketing \& Management, 31(4), 25-26.

Rekettye, G. (2004). Az érték a marketingben [Value in marketing - In Hungarian]. Marketing \& Management, 38 (2), 6-17.

Rekettye, G. (2008). Kisvállalati marketing [Marketing for SME-s - In Hungarian]. Akadémiai Kiadó, Budapest. pp. 24-25.

Sajtos, L., \& Mitev, A. (2007). SPSS Kutatási és adatelemzési kézikönyv [SPSS Research and data analysis handbook - In Hungarian]. Alinea Kiadó, Budapest.

Tomcsányi, P. (1994). Piaci áruelemzés és marketing termék-stratégia [Market commodity analysis and marketing product strategy - In Hungarian]. Országos Mezőgazdasági minősítő Intézet, Budapest. p. 181-184. in Veres Z. (2009). A szolgáltatásmarketing alapkönyve. Akadémiai Kiadó Zrt., Budapest. p. 94.

Veres, Z. (2009). A szolgáltatásmarketing alapkönyve [The basic book of service marketing In Hungarian]. Akadémiai Kiadó Zrt., Budapest. p. 33-94, 338-384.

Webster, C. (1991). Influences Upon Consumer Expectations of Services. The Journal of Services Marketing, 5 (1) Winter, 5-17. in Kenesei, Z. \& Kolos, K. (2007). Szolgáltatásmarketing és -menedzsment. Alinea Kiadó, Budapest. p. 136.

Zeithaml, V., \& Bitner, M. J. (1996). Services Marketing. McGraw-Hill, Maidenhead. 